\title{
Hematobiochemical alterations and gross pathology of liver fluke infestation in goat (Capra hircus) in Poonch Azad Kashmir
}

\author{
Ayesha Aslam ${ }^{1}$, Shahzad Akbar Khan ${ }^{2 *}$, Muhammad Tarique Tunio ${ }^{1}$ and \\ Muhammad Shehzad ${ }^{3}$ \\ 1. Department of Agricultural Sciences, Allama Iqbal Open University Islamabad-Pakistan \\ 2. Department of Pathobiology, Faculty of Veterinary \& Animal Sciences, University of the Poonch, Rawalakot- \\ Pakistan \\ 3. Department of Agronomy, Faculty of agriculture, University of the Poonch Rawalakot-Pakistan \\ *Corresponding author's email: shahzadakbar@upr.edu.pk
}

Citation

Ayesha Aslam, Shahzad Akbar Khan, Muhammad TariqueTunio and Muhammad Shehzad. Hematobiochemical alterations and gross pathology of liver fluke infestation in goat (Capra hircus) in Poonch Azad Kashmir. Pure and Applied Biology.Vol. 9, Issue 1, pp595-608. http://dx.doi.org/10.19045/bspab.2020.90065

\begin{tabular}{llll}
\hline \hline Received: 16/04/2019 & Revised: 03/12/2019 & Accepted: 13/12/2019 & Online First: 18/12/2019 \\
\hline
\end{tabular}

\section{Abstract}

Study was conducted on two hundred blood samples for hematobiochemical analysis where as two hundred liver samples were also collected after slaughter for routine histopathology. Age of the animals was determined on the basis of teeth and the animals were divided in to two groups, young and adult goats having hundred animals in each group. Subjective evidence of the disease was recorded on the day of slaughter. Clinical signs were recorded from goats before slaughter. Cumulative score of the macroscopic changes was determined in the form of hepatomegally, large areas of haemorrhages, change in consistency, presence of flukes, blockage of gall bladder and inflammation of gall bladder. Overall score of macroscopic changes inadult goats was quite higher than goats in young group. Biochemical and haematological study showed that there was increase in the concentration of glucose, urea, creatinine, triglycerides, Alanine transferases, Aspartate transferases, Alkaline phosphatises and Gammaglutamyl transferases in adult goats infected with liver flukes while there was sharp decrease of serum total protein in adult goats. In animals of young age group these parameters are not affected much. Macroscopic lesions noted during the study revealed changes on parenchyma and in billiary tract. Fibroblasts were evident in the areas migrated by flukes. Necrosis of hepatocytes, fibrosis and mononuclear cellular infiltration was detected in goats of adult age group in comparison to goats of young age group. It is concluded that fascioliasis caused considerable pathological alterations in hematobiochemical parameters as well as gross and microscopic changes in the liver of affected goats.

Keywords: Caprine Fascioliasis; Hematobiochemical; Macroscopic lesion; Necrosis

\section{Introduction}

Livestock is a key sector of Pakistan's providence. Livestock plays a key role from gross root level in e economy of country. Livestock necessitate fundamental role in safeguarding the lives of peoples of villages. Approximately $62 \%$ peoples of the country are living in the in villages and are involved with agriculture or livestock directly or indirectly for their livelihood. 
Impoverishment reduction through livestock raising has a pivotal part for reduction of poverty from the country. Livestock are in the form of cattle, buffalo, sheep, goat, camels, horses, asses and mules and they produce milk, meat, wool, hair, bones, fat, blood, eggs, hides, and sins. Meat and milk has a major role in reduction of malnourishment to human being. Sheep and goat are major source of mutton.

Incidence of liverfluke infestation in sheep and goats was recorded as $12.70 \%$ [1]. Incidence of Fasciola hepatica in sheep of Southern Punjab Pakistan was noted $21.41 \%$ [2]. 2011). The prevalence of liverfluke infestation in sheep and goats of azad Kashmir was recorded as $73.2 \%$ by [3]. Liverfluke infestation in sheep and goats of Punjab were recorded as 62\% [2] similar study was conducted in sheep by [4].

Keeping in view the impact of the Fasciliasis this study has been designed to find out the hematobiochemical alterations and gross pathology of liver fluke infestation in goat (Capra hircus) in Poonch Azad Kashmir.

\section{Materials and methods}

\section{Study Area}

For the study samples were collected from districtPoonchAJK. This study is an effort to explore the health problem associated with FasciolaSpp in goats. For the study histopathological examinations of liver of goats, for biochemical analysis blood samples of goats were collected.

\section{Survey of abattoirs and butchers}

Different abattoir and slaughter houses were visited for prevalence of fascioliasis in district Poonch, Azad Jammu and Kashmir from goats having different ages. The blood was collected from fascioliasis infected goats similarly infected livers and gall bladders were also collected in $10 \%$ formalin from goats brought in slaughterhouse for slaughter.

\section{Collection of samples}

For the study 200 blood samples were collected from goats before slaughter, similarly, 200 livers were also collected from goats after slaughter. According to age of goats were separated in two groups, one was adult group and other was young group having 100 animals in each group.

\section{Macroscopic study}

The livers were examined externally and internally for the presence of parasites, nodules abscesses, tumors, fatty change, calcifications, necrosis, fibrosis, pigmentation and hepatitis. After slaughter, visual examination of carcasses and organs was done with keen attention being directed to livers.

\section{Histopathological study.}

At slaughter, gross lesions in livers of different age group of animals were carefully recorded. The livers collected were scored for gross lesions. Representative samples were collected in $10 \%$ neutral buffered formalin for histopathological examination. Tissues were passed from different chemicals and after that embedded in paraffin wax, section of 4 to 5 um was made with help of microtome and mounted on clean glass slides .Tissues were stained with $\mathrm{H} \& \mathrm{E}$ and examined under light microscope.

\section{Research design}

Total of two hundred goats were selected for study purpose. They were divided in to two groups as adult group and young group on the basis of teeth and physical condition, 100 samples each of blood and livers of adult group of goats were compared with 100 samples each of blood and livers from young animals.

\section{Serum biochemical analysis}

Samples of blood were collected from representative animals at the time of slaughter for evaluation of glucose, urea, triglycerides, uric acid, creatinine, alanine aminotransferases, aspartate aminotransferases, alkaline phosphatase, 
Gammaglutamyl transferases and serum total protein using commercially available kit of (AMEDA Labordiagnostik $\mathrm{GmbH}$ Germany).All the biochemical experiments were performed with Microlab-300.

\section{Statistical analysis}

Homogeneity (Levin's tests) and normality (Kolmogorov tests) tests were performed before analysis of data. Data was analyzed by one-way ANOVA. Data were considered significantly different when $P$ values were less than 0.05 .

\section{Results and discussion}

Clinical and gross pathology

Objective evidence and macroscopic changes of liver fluke infestation were observed in the groups of goats antemortem and post mortem. A subjective analysis of the macroscopic and macroscopic changes were noted in the form of increase in the size of liver, Change in color of liver to pale, Change in the consistency of liver (friability), areas with bleeding, identification flukes from ducts, bile duct blockage and inflammation of bile ducts. The overall score of macroscopic changes in adult goats were significant high in relation to young goats. The overall and cumulative score of gross lesions is elaborated in (Table 1).

Table 1.Cumulative gross lesional score in the liver of goats affected with fascioliasis

\begin{tabular}{|c|c|c|c|c|}
\hline \multirow[b]{2}{*}{ Organ } & \multirow[b]{2}{*}{ Lesion } & \multirow{2}{*}{$\begin{array}{c}\text { Maximum } \\
\text { possible Score }\end{array}$} & \multicolumn{2}{|c|}{ Groups } \\
\hline & & & $\begin{array}{c}\text { Adult group of goats } \\
(\mathbf{1 0 0})\end{array}$ & $\begin{array}{c}\text { Young group of } \\
\text { goats }(100)\end{array}$ \\
\hline \multirow{7}{*}{ Liver } & Enlarged liver & 10 & 8 & 6 \\
\hline & $\begin{array}{c}\text { Change of liver color } \\
\text { to pale }\end{array}$ & 10 & 8 & 4 \\
\hline & Friable & 10 & 10 & 6 \\
\hline & Hemorrhagic areas & 10 & 10 & 4 \\
\hline & Flukes detection & 10 & 10 & 4 \\
\hline & Bile duct obstruction & 10 & 8 & 4 \\
\hline & $\begin{array}{l}\text { Inflammation of bile } \\
\text { duct }\end{array}$ & 10 & 8 & 6 \\
\hline $\begin{array}{c}\text { Overall } \\
\text { Gross } \\
\text { lesions } \\
\text { score of } \\
\text { liver }\end{array}$ & & 70 & 62 & 34 \\
\hline
\end{tabular}

\section{Serum biochemical analysis}

Concentration of blood glucose was determined for animals of both adult and young groups of goats. A hyperglycemia in adult goats was noted in contrast to young group of goats.

It was recorded in the investigations that as the animals become aged their blood glucose level become high in relation to blood glucose of young animals similarly During the study creatinine concentration was also measured. It was observed that concentration of creatinine was significantly lower in aged group of goats in relation to young animals (Figure 1). 
Blood Urea Nitrogen was studied during the investigation. It was worth mentioning that in this study blood urea nitrogen concentration was quite significantly lowered in adult of goats in comparison goats of young animals. While lesser blood urea nitrogen was noted in young goats in relation to adult goats (Figure 2).

Triglycerides concentration was measured using commercially available kit. Triglyceride concentration was measured from the blood of goats of 2 different age groups. It was noted that there is overall an increase in the concentration of triglycerides in animals of adult group whereas concentration of triglycerides was found in normal limit in the blood of young aged group animals (Figure 3 ).

A significantly lowered creatinine concentration is directly related to muscle loss due to presence of less protein which is quite helping for reversal from anemia (Figure 4).

Liver function tests were performed for knowing the functioning ability of the liver. Blood biochemical profile of adult group of animals were studied for comparison with young animals. As comparing the blood biochemical profile of adult animals with young animals, it was quite evident that increased activity of serum ALT and AST ( $\mathrm{P}<0.05$ )were recorded (Figure $5 \& 6$ ). The Blood liver AST, ALT and ALP concentrations were directly related with pathological damages, it means higher the pathological damage to liver by liverflukes, there is highest damage to liver as the structural chnges are depicting with higher concentrations of AST, ALP (Figure 7) and ALT. Present results are too much different when comparing two groups.

Malnutrition is also contributing factor for the disease. Gammaglutamyltransferase concentration was also determined in both the young and adult groups of goats. The increase in the level of GGT in aged group of goats when compared with young animal group, in adult animals this enzyme concentration was increased as in prolonged liverfluke infestation (Figure 8).Increased level of GGT has reflected the too much damage of liver in relation to young group of animals. Findings of this study has clearly indicated that liverfluke infestation has effect on protein metabolism as well. As hypoproteinemia was observed with fascioliasis due to destruction of hepatocytes and hepatic parenchyma which might results in improper utilization and accumulation of serum total protein synthesis.

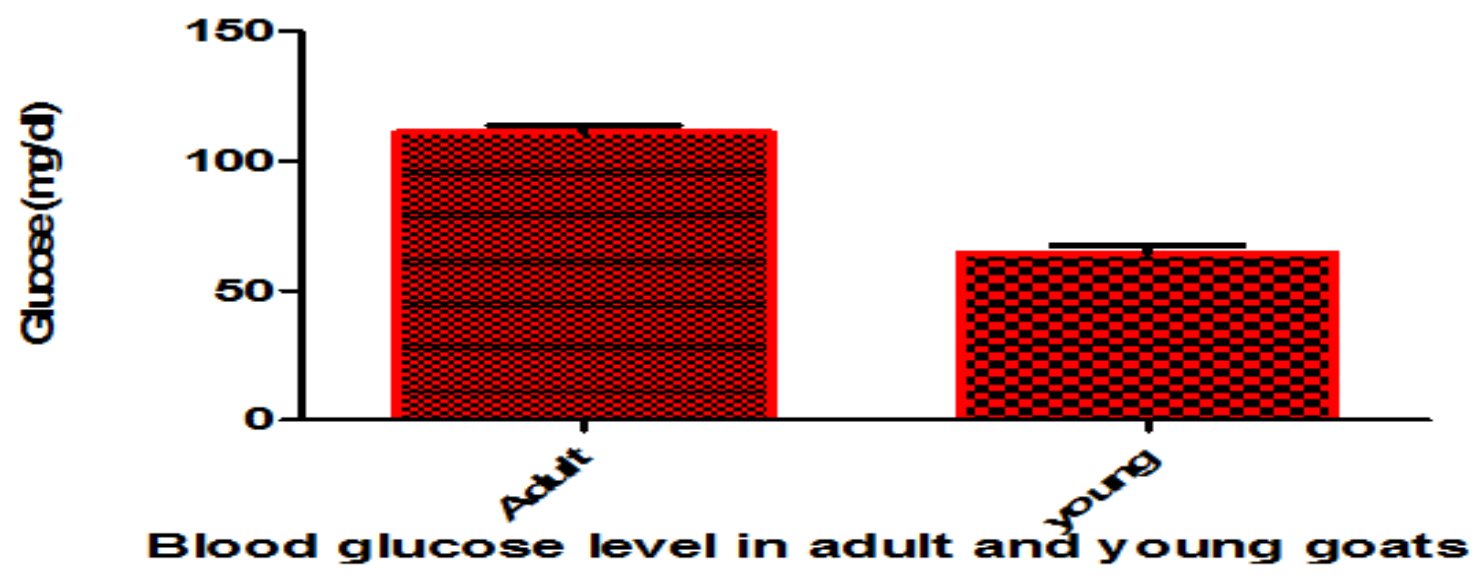

Figure 1. Blood glucose Concentration in adult and young goats $(P<0.05)$ 


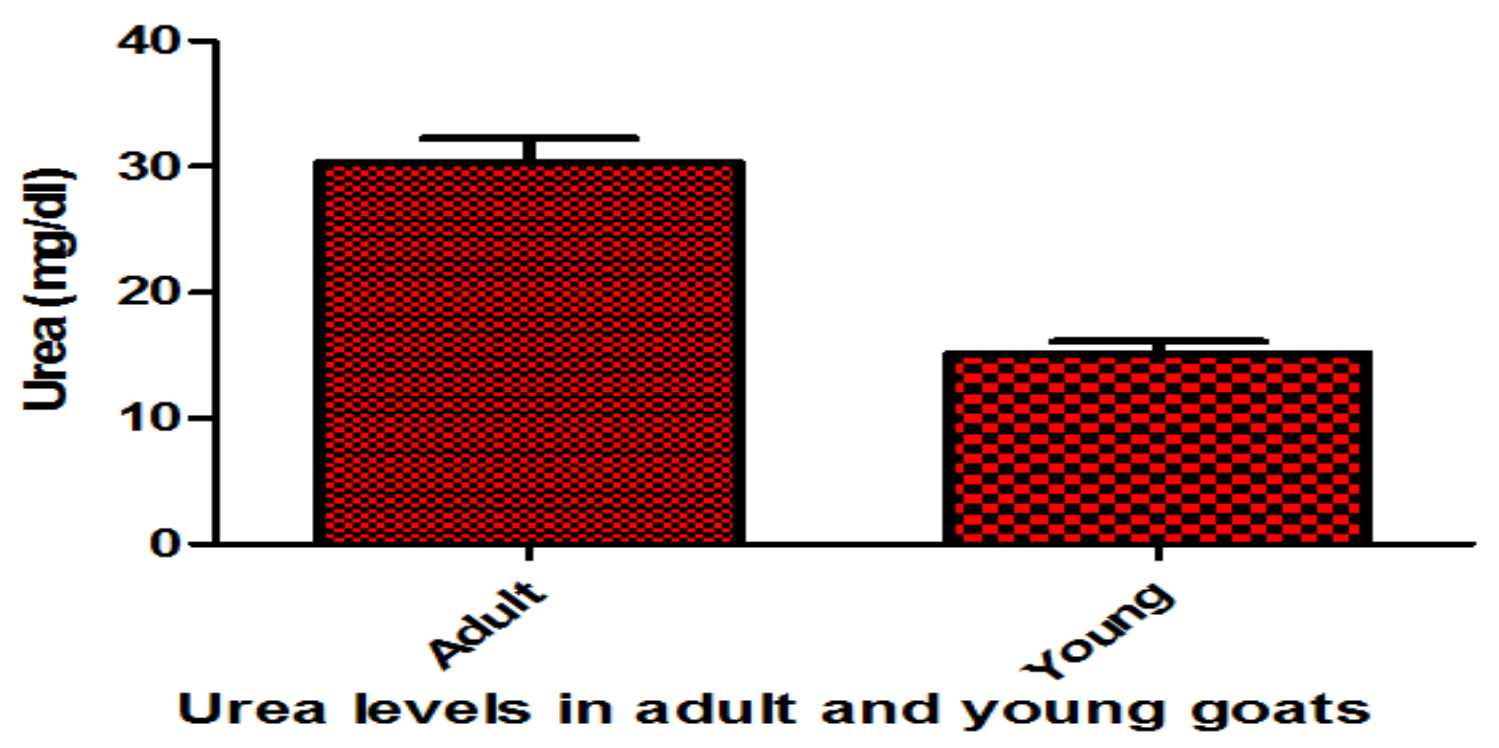

Figure 2. Blood Urea Nitrogen concentration in adult and young goats $(\mathrm{P}<0.05)$

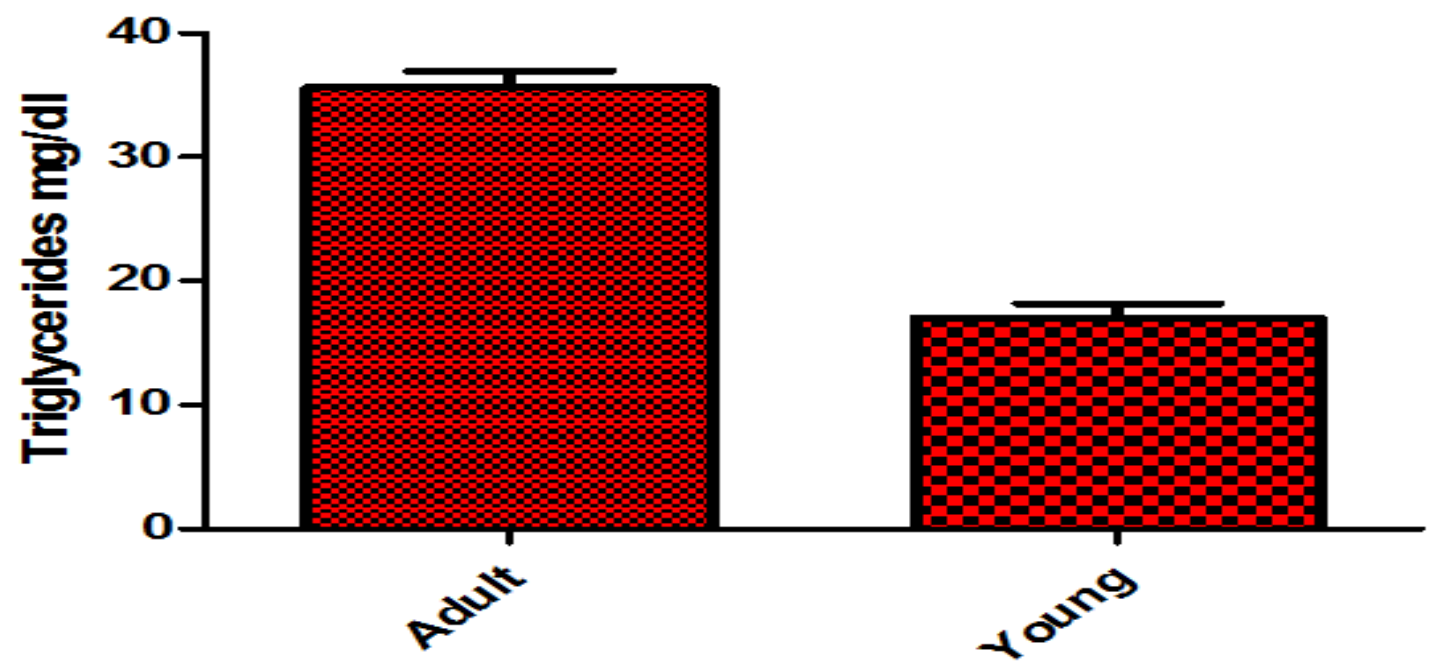

Triglycerides levels in adult and young goats

Figure 3. Triglycerides levels in adult and young goats $(P<0.05)$ 


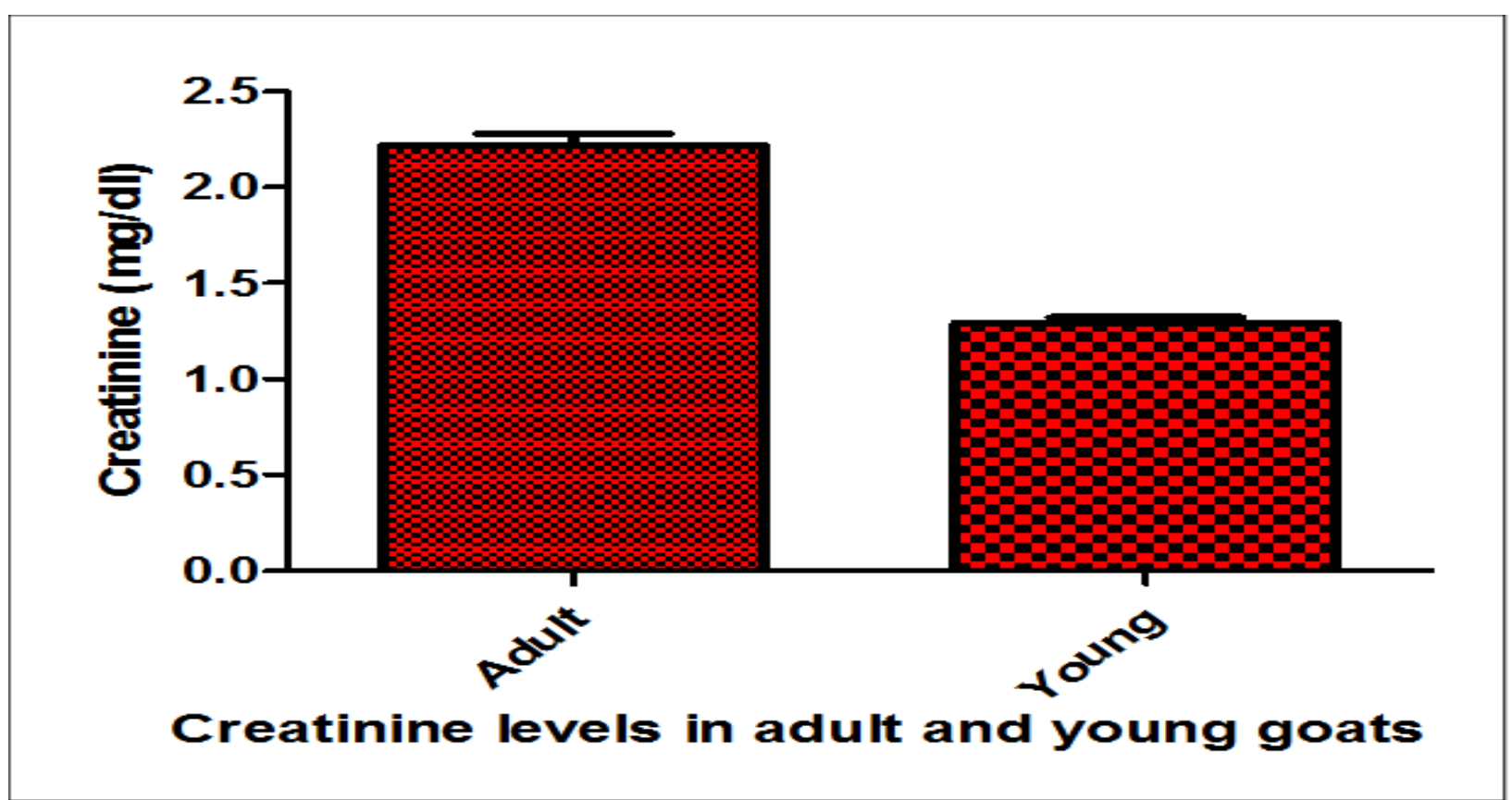

Figure 4. Creatinine concentration in adult and young goats $(P<0.05)$

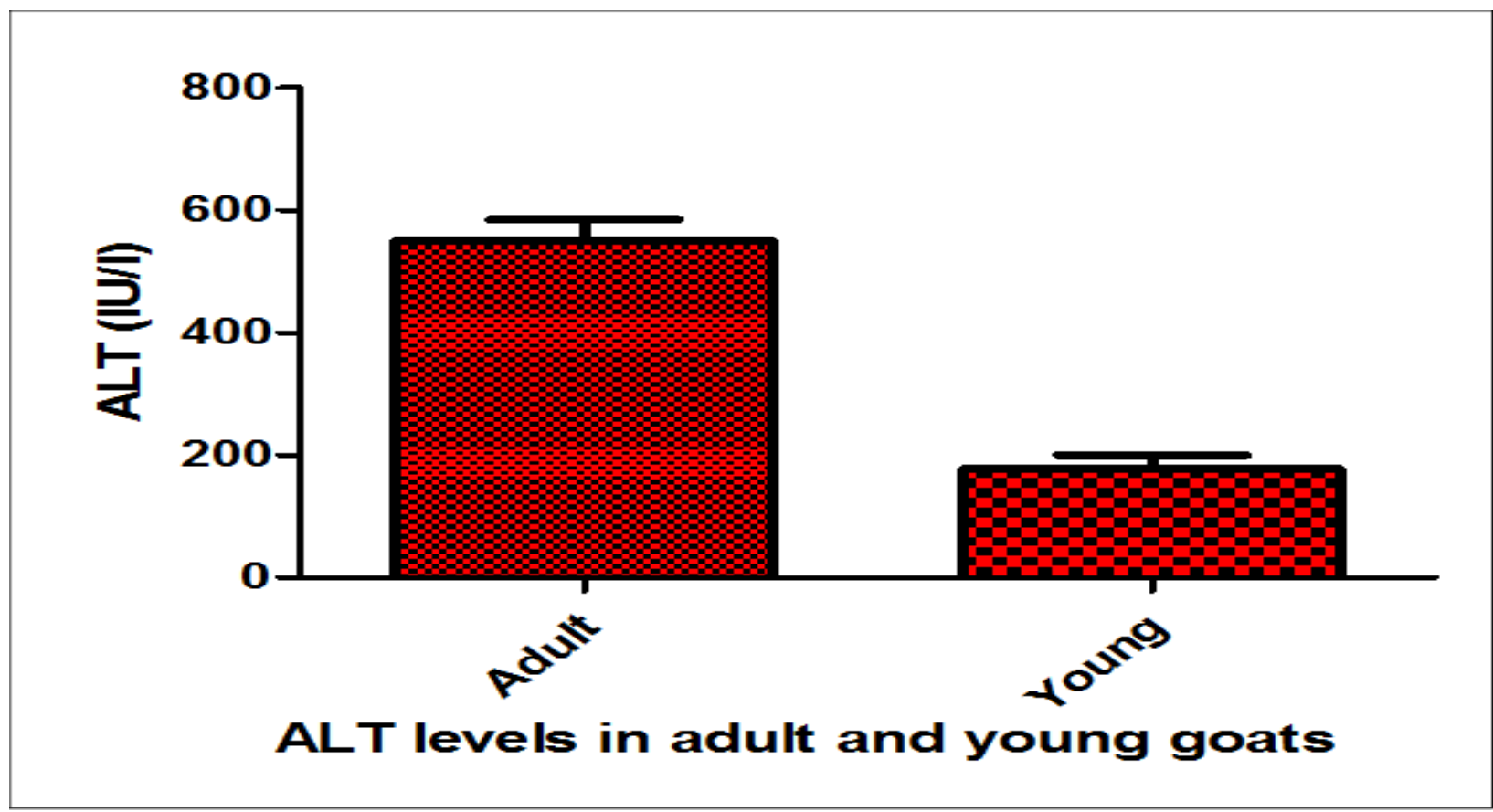

Figure 5. ALT values in adult and young goats $(\mathrm{P}<0.05)$ 


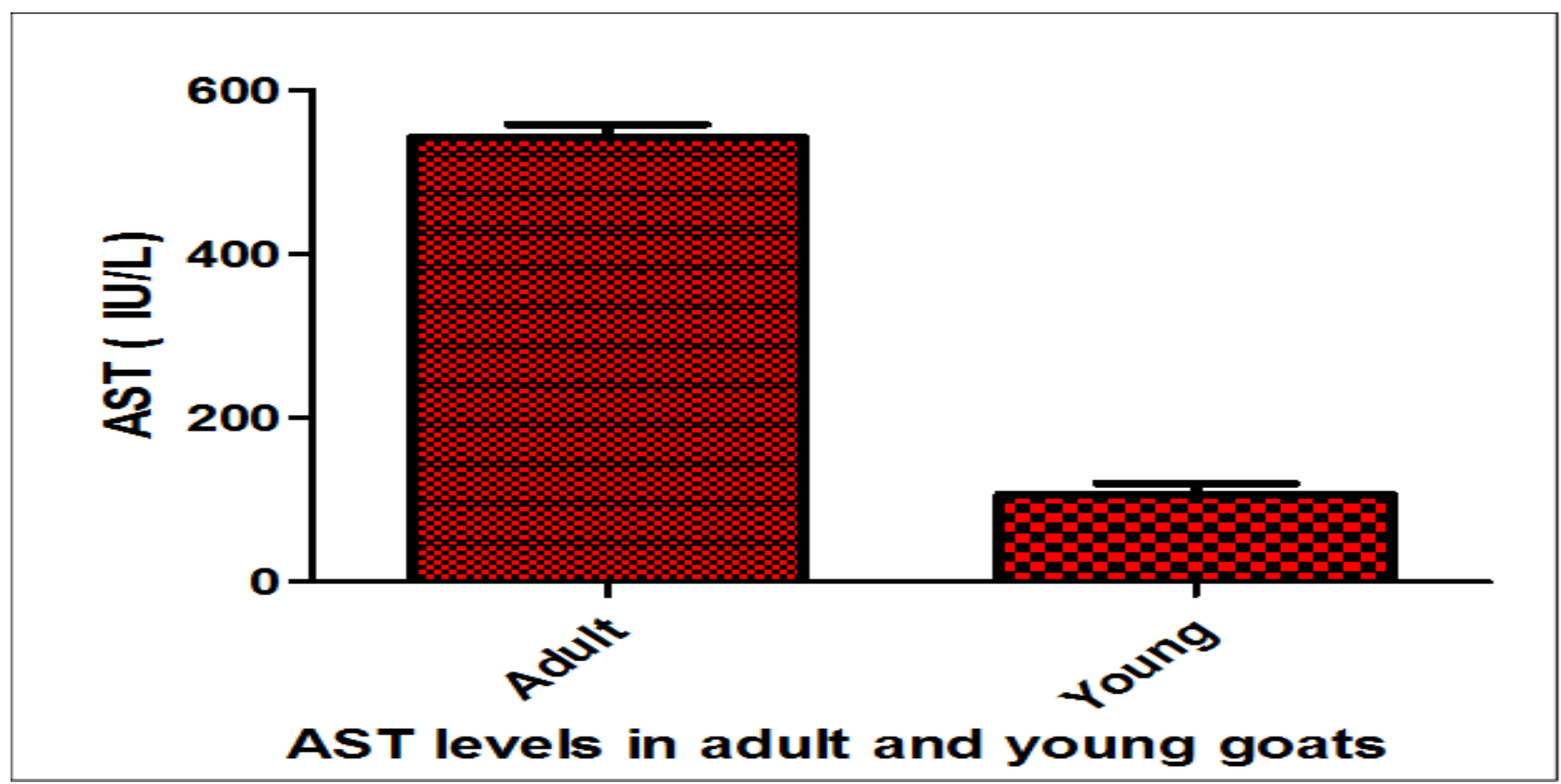

Figure 6. AST levels in adult and young goats $(\mathrm{P}<0.05)$

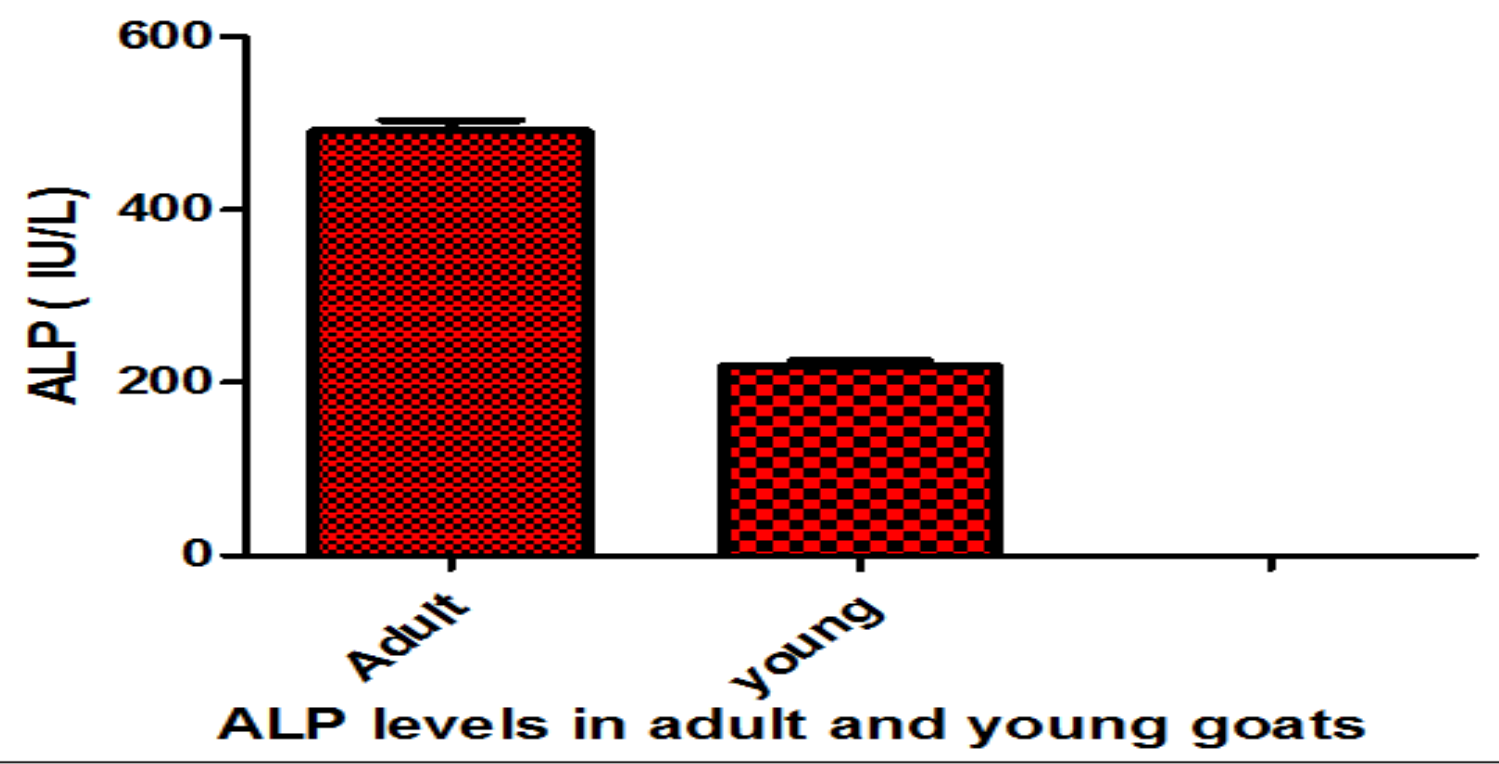

Figure 7. ALP levels in adult and young goats $(\mathrm{P}<0.05)$ 


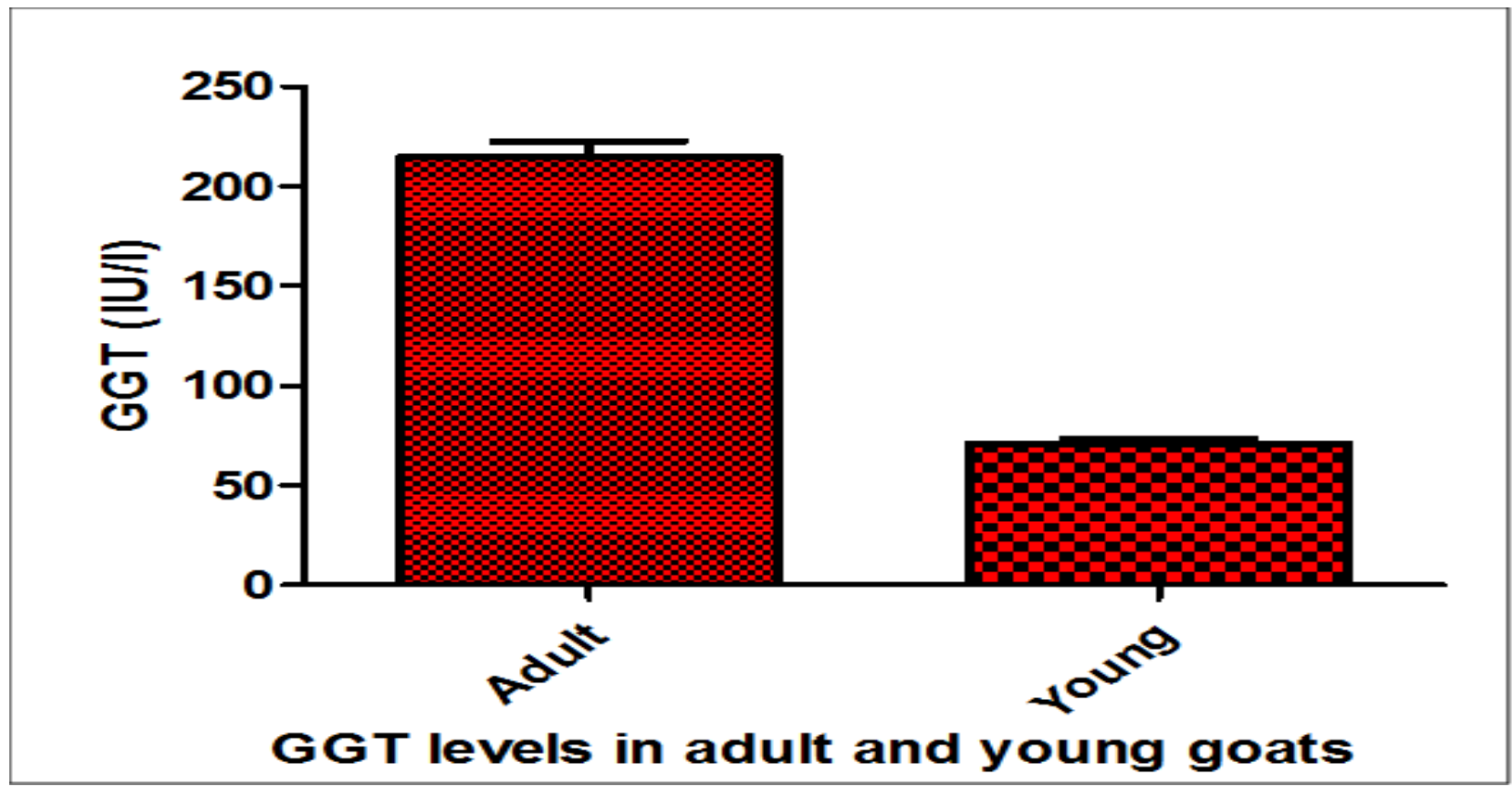

Figure 8. GGT Levels in adult and young goats $(\mathrm{P}<0.05)$

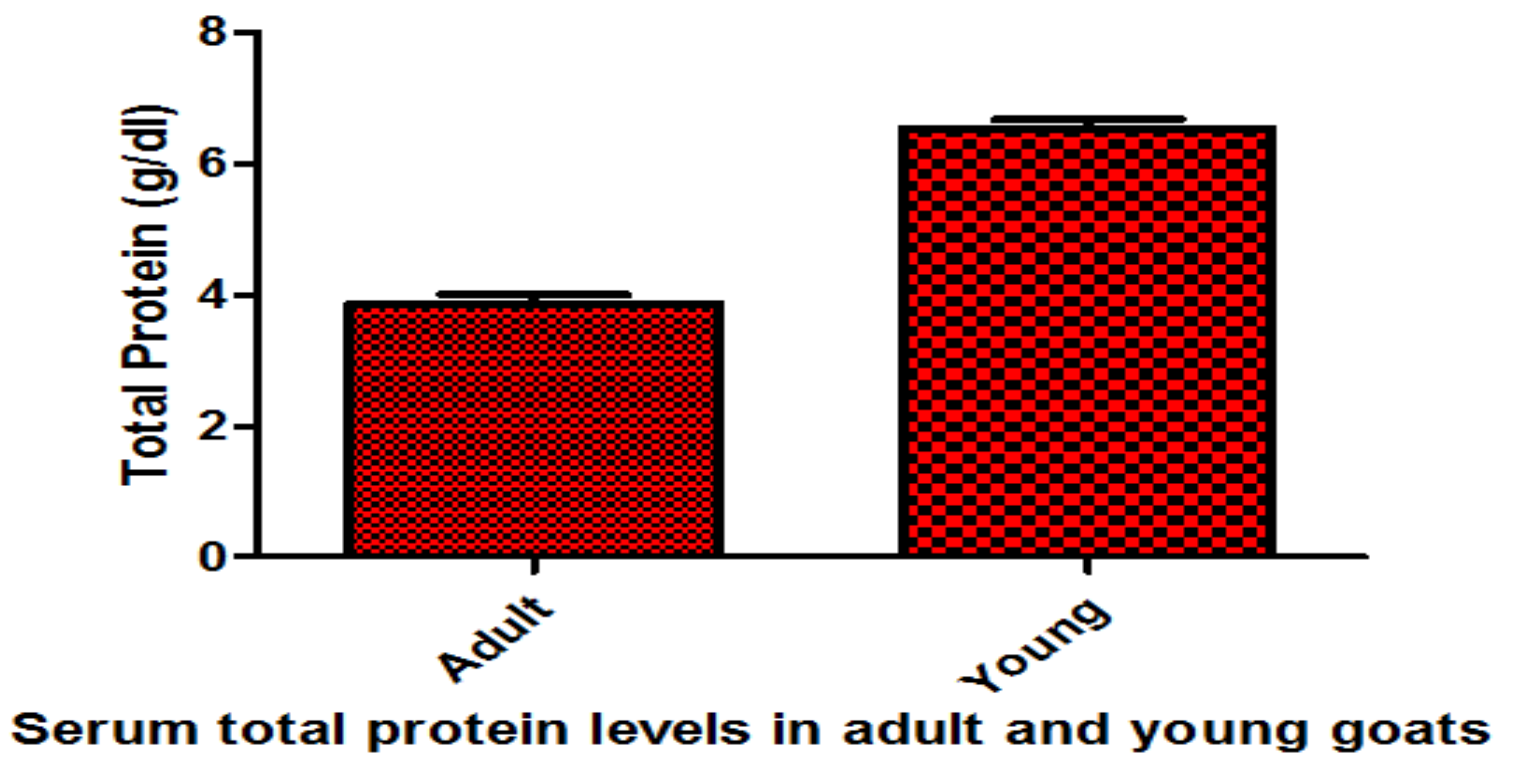

Figure 9. Serum total protein levels in adult and young goats $(\mathrm{P}<0.05)$

Identification of liver fluke from bile ducts and gall bladder

Samples from entire liver were placed in a container and incised with scalpel in the deeper part of the liver in such a manner so that blood vessels become evident from the incised part along with portal vessel, gall bladder and bile ducts. Mature as well as immature flukes were taken out with great care in order to avoid tissue trauma.Liver flukes thus obtained were clearly washed three times with normal saline and fixation 
of the tissues was carried out with formaline acetic alcohol.

\section{Gross and microscopic studies}

Representative liver tissues from adult and young groups of goats exhibited high degree of paleness, jaundice, dropsy of region under the mandible.Macroscopically there was peritonitis, thick dense connective tissues were aggregated in too much amount and inflammatory fluid accumulation with depots of fibrin in the area.After post-mortem tissues were preserved in $10 \%$ neutral buffered formaline for demonstration of microscopic changes. Histologically lesions were recorded typical of severe liverfluke infestation. Perivascular tissues of the were showing too much growth which contain immature flukes. Hepatocytes were necrotic, blackish and contain mononuclear cellular infiltration. Bleeding was evident with invasion of mononuclear cells. Hemorrhagic areas were seen in the liver parenchyma with nodular appearance along with migration of liver flukes. Microscopically liver of the adult goats showed less hepatocytes and less sinusoids (Figure 10), Polymorphonuclear leukocytes infiltration in the portal region was evident. Hepatic cords were running in various directions with disorganization and growth of granulation tissues in the bile ducts. Somes areas of the liver were congested with necrosis of liver parenchyma and fatty degeneration and vacuolation of hepatocytes in the central areas of the liver in young group of animals (Figure 11). In per acute cases of liverfluke infestation hydropic degeneration infiltration of large number of neutrophils were seen in hepatocytes.

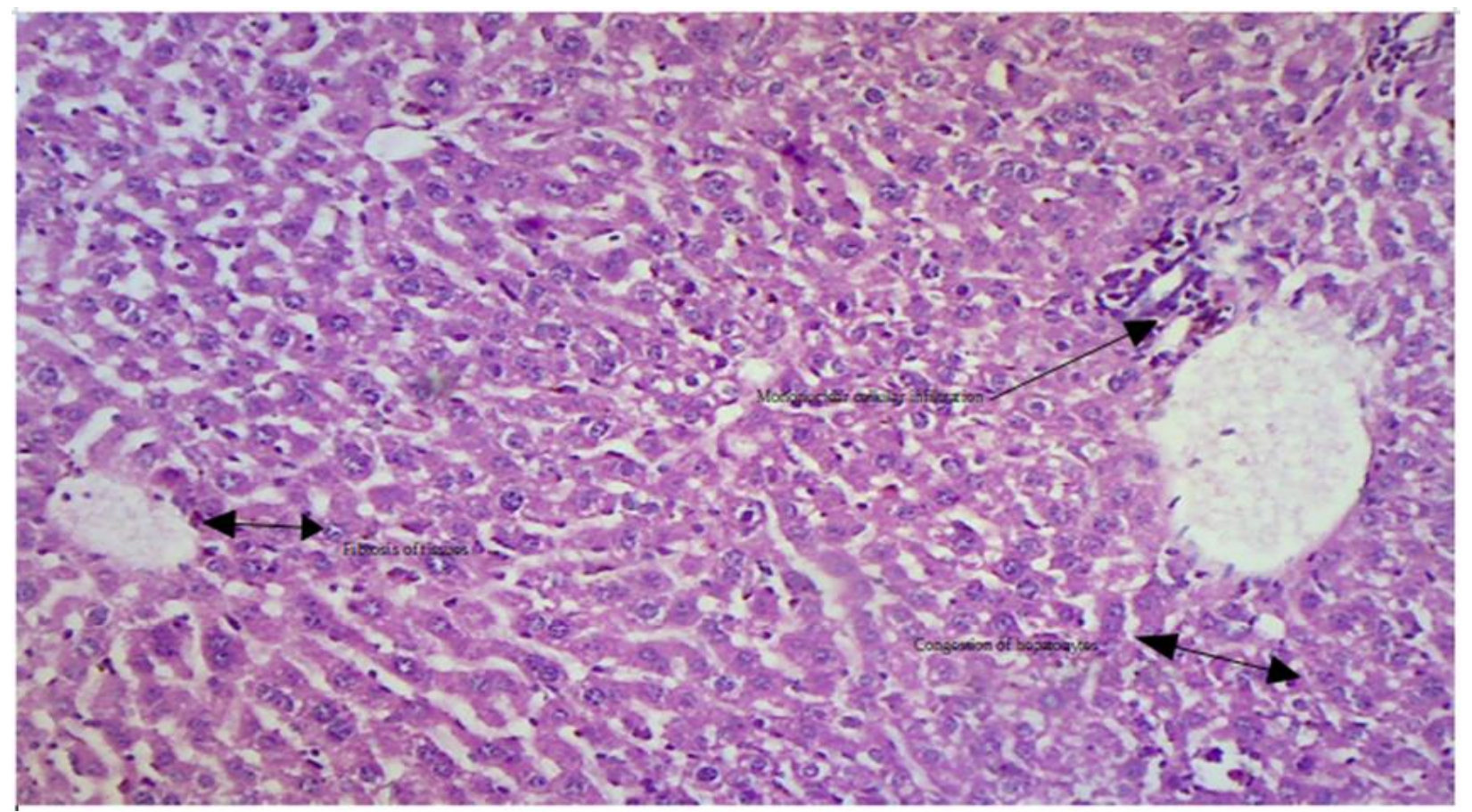

Figure 10.Microscopical changes in the liver of goats of aged group 


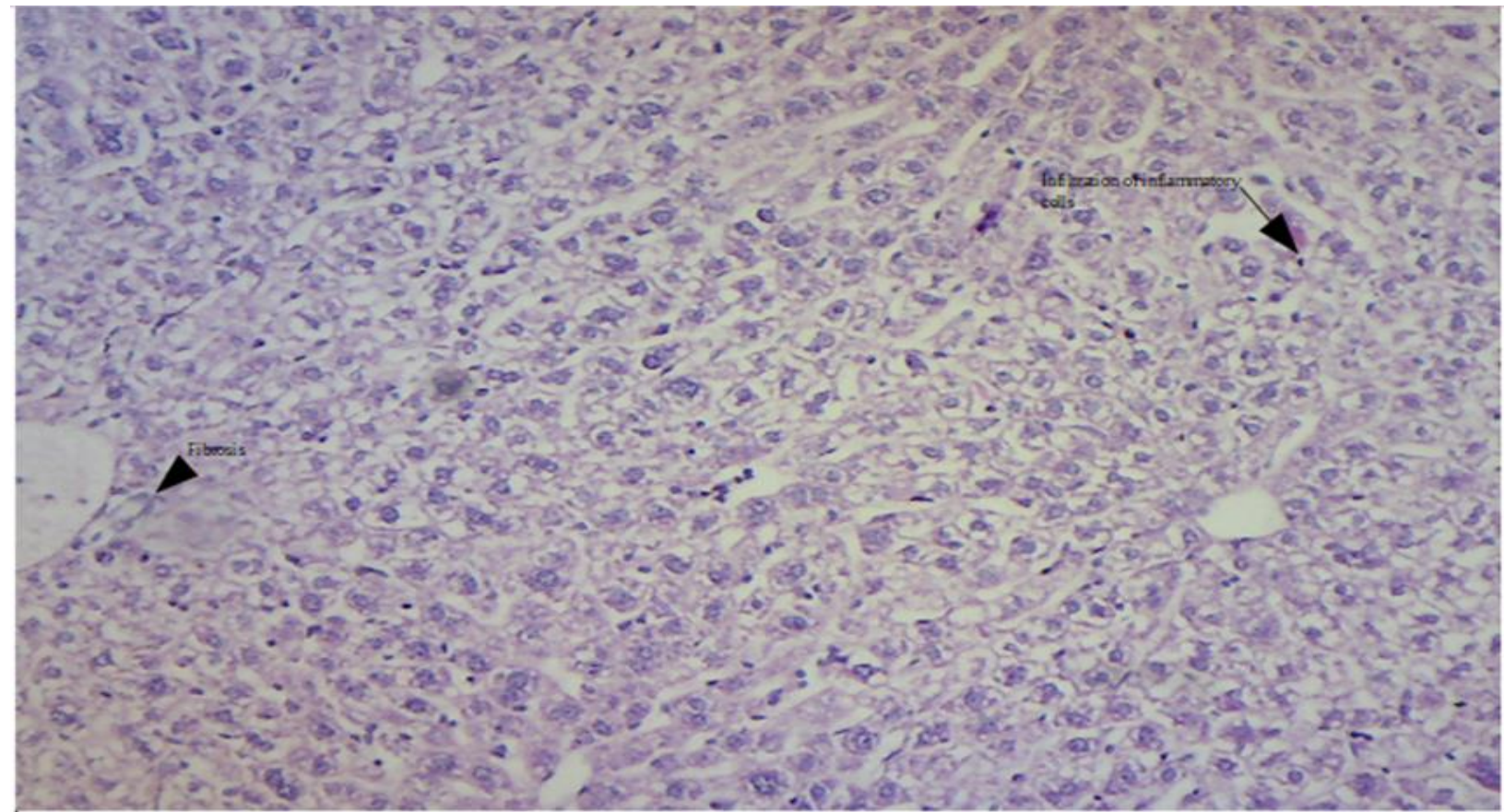

\section{Figure 11. Histological lesions in the liver of goats of young group}

This study elucidates that the gross pathological lesions observed in the hepatocytes of goats are quite similar with the exception of fewer areas where calcification was noted in adult goat hepatocytes. In chronic cases size of the liver become variable, liver having raised elevated areas, pinpoint hemorrhages were seen on parietal surface of liver parenchyma. Bile duct become too much thick with distended areas (Figure 12). In acute cases liver become enlarge, jaundice become evident with bleeding on parietal surface.

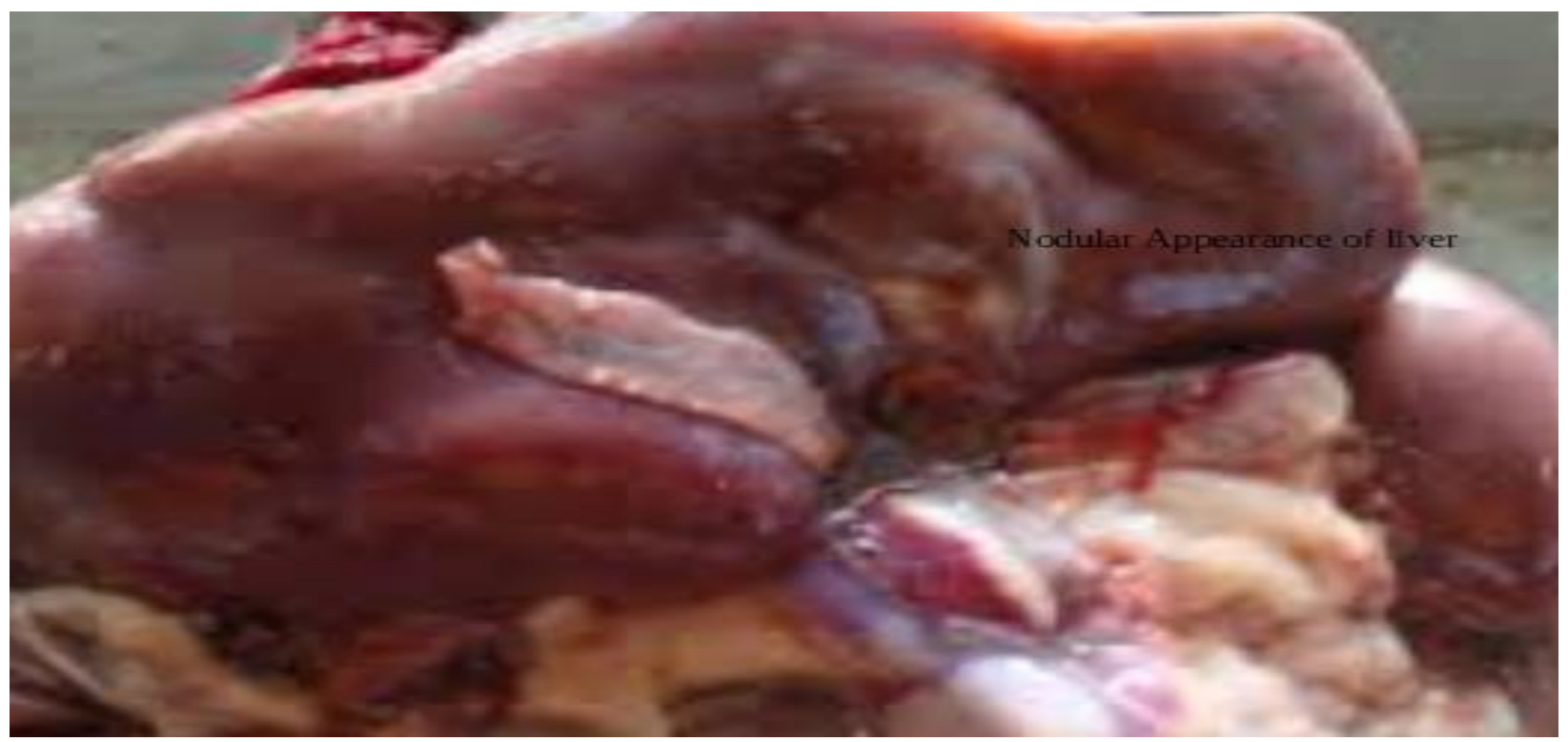

Figure 12. Macroscopic appearance of liver of goat Fasciolosis 
It is very clear in the study that lesions in the bile duct as well as parenchyma were noticed in the study. Accumulation of fibroblasts, lymphocytes, plasma cells and macrophages were noted in the damaged areas with mild growth of fibrous tissues (Figure 11), increase in the size of cells of bile duct are the changes noted in prolonged cases.

Histopathologically bile duct showed some changes as compared to liver parenchyma in severe cases of the fascioliasis. The path from where liverflukes have travelled were infiltered with macrophages and eosinophils (Figure 11). Inflammation of various areas of the hepatocytes with death changes and less colored cytoplasm, karyorhexis and karyolysis were observed.

\section{Discussion}

Fascioliasis is documented in most of the parts of the Pakistan, however this is the first study about liverfluke infestation in goatsindistrictpoonchzadKahmir. For this study animals from both young as well as adult group was included in the study in order to determine clinical, hematobiochemical, microscopic lesions examination. Most of the profile of the biochemical, histological changes were quite higher in aged goats than normal, while the same parameters were quite in line in young goats because of their immunity irrespect of the presence of flukes in both groups of animals and these findings are in close agreement to the findings of $[5,6]$ irrespect of the level of blood urea nitrogen and albumin whose level was elevated than normal because of the possibility of grazing of animals on forage legumes.

\section{Clinical and grosspathology}

Dropsy of the area under the mandibular region was observed in both the groups of animals as aged and young goats. Gross pathological lesions have shown in the form of enlargement of liver, jaundice condition of hepatocytes, recovery of flukes, blockage of billiary tract and inflammation of bile duct in adult goats whereas severity of the infection was quite less in young animals, these findings are in line with the findings of [7], as they determined bleeding from parietal surface of the liver in chronic liver fluke infestation from goats farm. Areas of hepatic damages were evident at the routes of migration of the immature parasites in the liver parenchyma [8]. In close with the findings of [9-11] chronic infections of the present study had showed liver with consolidated areas, hard in consistency and calcification of the some of the areas along the bile ducts. It was of the opinion that it might be due to immunological reaction of macrophages and lymphocytes infiltration that accounts with fibrotic healing of the necrotic areas during the chronic stage of liverfluke infestation. Continuous irritation of the tissues in the cells of bile ducts caused cholangitis, thickening of the wall of bile ducts intra- and extrahepatic biliary dilatation [12].

\section{Blood biochemical profile analysis}

Findings of the present investigation had elaborated that biochemical profile including blood glucose, liver enzymes (Alanine Transferases, Aspartate Trasferases, Alkaline Phosphatases and Gamma Glutamyl Transferases), urea and creatinine were significantly elevated $(\mathrm{P}<0.05)$ and there was decline in total protein $(\mathrm{P}<0.05)$ in Fasciola infested goats in relation with young animals. Findings of the present investigations are in line with those studied by[8] who determined a highly increase in enzyme levels(Alanine Transferases, Aspartate Trasferases, Alkaline Phosphatases and Gamma Glutamyl Transferases) in liverfluke infected sheep and goats [13, 14] elaborated an increase of AST concentration two weeks after infection in relation to migratory immature flukes in the liver parenchyma. They emphasized that damage to liver is a conducive factor for increase of serum Alanine Transferase activity in the infested goat. 
It is very clear from the study that Fasciola spp. Are important source of induction of release of reactive oxygen species that pose damage to cell membrane and necrosis of hepatocytes. These microscopic and macroscopic changes have direct effect on alteration of biochemical parameters in blood including liver specific enzymes $[4,15]$. It is very clear that different liver enzymes have different activities like Alanine Transferases, Aspartate Trasferases, Alkaline Phosphatases and GammaGlutamyl Transferases, Triglycerides in blood are generally a clear indicator of pathological lesionss of tissue and organ $[4,16]$. In close agreement to the results of the this study haave demonstrated changes in Alanine Transferases, Aspartate Trasferases, Alkaline Phosphatases and Gamma Glutamyl Transferases values between cattle, sheep and goats affected by different stages of liverfluke infestation as compared with animals with no fasciolosis. As leakage of these enzymes takes place when there is damage to liver by flukes which results in high level of serum liver enzyme [17].

Many other studies are elaborating little or no effect of liverfluke infestation on feed intake and Blood urea nitrogen levels $[18,19]$, the results of significantly highblood urea nitrogen as compared with the young goats are indicative of protein metabolism estimation during prolonged liverfluke infestation.

\section{Macroscopic and microscopic examination}

Migration of larvae of the flukes may pose a threat to liver damage, especially in goat spp, which in turn have bad effects. Fibrosis of hepatic cords with hemorrhages in the bile ducts and liver parenchyma may occur by flukes.Highest sick rate in small ruminants whereas high death rate in lambs was documented [20]. A condition of inflammation of hepatocytes cysticercosis, caused by $C$. tenuicollis in sucking pigs, was described by [21-23]. Pullin, [24] demonstrated severe hemorrhagic tracts in the superficial areas of the liver of lambs that were experimentally infected with this parasite. In second study [25], determined study and made a conclusion that, liver become hemorrhagic by migration of flukes, as fibrosis of Glisson's capsule and inflammatory reaction in and around of the cyst. During this study, the infested goats with C. tenuicollis, demonstrated large concentric foci of hemorrhages at the parenchyma of liver at postmortem examination. In histopathological evaluation less number of liver cells were noted., dilation of sinusoids, presence ofmononuclear inflammatory cells in bile duct areas and double layered parasitic cyst formation in prolong cases were evident.

\section{Conclusion}

Liverfluke infestation posed marked pathological changes in the hepatocytes of liver of both adult and young goats.It was concluded that Fascioliasis in goats caused increase levels of liver enzymes along with increased concentration of glucose, triglycerides and creatinine.Blood total protein was also reduced by liverfluke infestation in adult goats. Variable degrees of histopathological lesions were noted in the form of hemorrhages, death of cells, hyperplasia of cells and fibrous connective tissues and infiltration of polymorpho mononuclear cells were also noted in adult goats.

\section{Authors' contributions}

Conceived and designed the experiments: SA Khan \& A Aslam, Performed the experiment: SA Khan \& A Aslam, Analyzed the data: SA Khan, Contributed reagents/ material/ analysis tools; SA Khan \& A Aslam, Wrote the paper: SA Khan \& A Aslam.

\section{References}

1. Mazyad SA \& El-N (2002). The endoparasites of sheep and goat, and 
shepherd in North Sinia Governorate, Egypt.J Egypt Socparasitol 32: 119-126.

2. Lashari MH \& Tasawar Z (2011). Prevalence of Some Gastrointestinal Parasites in Sheep in Southern Punjab, Pakistan. Pak Vet J 31(4): 295-298.

3. Khan SA, Muhammad S, Khan MM \& Khan MT (2015). Study on the prevalence and gross pathology of liver fluke infestation in sheep in and around Quetta District, Pakistan. AdvAnim Vet Sci 3(3): 151-155.

4. Khan SA, Ahmed N \& Tunio MT (2019). Incidence of liver fluke infestation and pathological examination in sheep (Ovisaries) in Mirpur Azad Jammu and Kashmir. Pure and Appl Biol 8(1): 750-761.

5. Kramer JW (2000). Normal hematology of cattle, sheep and goats, pp 1075-1084.

6. Kaneko JJ, Harvey JW \& Bruss ML (1997) Clinical Biochemistry of Domestic Animals, 5th Edn. Academic, San Diego, pp 890-894.

7. Okaiyeto SO, Salami O S, Dnbirni S A, Allam L \& Onoja II (2012). Clinical, Gross and Histopathological Changes Associated With Chronic Fasciolosis Infection in a Dairy Farm. $J$ Vet $A d v$ 2(8): 444-448.

8. Borai MGE, Abdel-Rehiem A, Nagi MS, Gab-Allah AB, ElMashad I \& Shawky AM (2013). Comparative pathological studies on parasitic affections of liver in farm animals. Benha Vet Med J 25(2): 284-295.

9. Jones EA, Kay JM, Milligan HP \& Ownez D (1977). Massive infection with Fasciofa hepatica in man. Am J Med 63: 803-842.

10. Molina EC, Skerratt LF \& Campbell R (2005). Pathology of fasciolosis in large ruminants. Overcoming liver fluke in South East Asia, pp 94-126.

11. Sayed SM, Gehan MS \& Neveen AE (2008). Clinicodiagnosticstudies on hepatic affections of aged buffaloes. Assi Vet Med J 54(117): 310-328.

12. Catalano OA, Sahani DV, Forcione DG, Liu CB, Hsien C, Soricelli A, Arellano RS, Muller PR \& Hahn PF (2009). Biliary infections: Spectrum of imaging findings and management. Eur J Pediatr 29(7): 25-43.

13. Doaa FT, Soliman EK \& Abd El-Khalek TMM (2007). Effect of Fascioliasis on hematological,serum biochemical and histopathological changes in sheep. Egypt J Sheep Goat Sci 2(2): 15-34.

14. Singh J, Bal M, Aradhana $S \&$ Gumber $S$ (2004). Efficacy of different flukicides against fascioliosis in sheep and goats. $J$ Res 41(2): 287-289.

15. HodzicA, Zuko A, Avdic R, Alic A, Omeragic J \& Jazic A (2013). Influence of fasciolahepatica on serum biochemical parameters and vascular and biliary system of sheep liver. Ira .J. $\mathrm{Pa}$ rasitolJones TC, Hunt RD \& Kind NW (1997). Veterinary pathology; 6th ed, Lea Febiger, Philadelphia, USA. 146-68.

16. Tanritanir P, Ozdal N, Ragbetli C, Yoruk I, Ceylan E \& Deger S (2009). Some biochemical parameters and vitamins levels in the hair goats naturally mixinfested with ectoparasites (Lice (Linognathus africanus) and Trichostrongylidae spp.). J Vet Adv 8(3): 590-594.

17. Mert H, Kozat S, Ekin S \& Yörük I (2006). Serum sialic acid, lipid-bound sialic acid levels in sheep naturally chronic infected with $F$ hepatica Sag Bilim Der 9: 40-46.

18. Anderson PH, Berret S, Brush PJ, Hebert CN, Parfitt JW \& Patterson DS (1977).Biochemical indicators of liver injury in calves with experimental fascioliasis. Vet Rec 100: 43-45.

19. Sykes AR, Coop RL\& Rushton B (1980). Chronic subclinical fascioliasis 
in sheep: effects on food intake, food utilisation and blood constituents. Res Vet Sci 28(1):63-70.

20. Soulsby EJL (1986). Helminths, arthropods and protozoa of domesticated animals, $7^{\text {th }}$ Edn. Baillier Tindall, London, pp 113-115.

21. Bertullo VH (1943). Hepatitis cysticercosa de los lechones ocasionada per el Cysticercus tenuicollis de la Taenia marginata. Bul Min Direction Gana Montevideo 27: 429-434.

22. Lloyds TS (1964). Hepatitis cysticercosa causing sudden death in a pig. Vet Rec 1076:1080
23. Karasev NF (1978). Distribution, clinical manifestation and pathology of Taenia hydatigena and Cysticercus tenuicollis in animals in Belorusia. Dostizh Vet Nulki Peredovog Zhivotnov 55: 77-79.

24. Pullin JW (1955). Observation on the liver lesions in lambs experimentally, with cysticerci of Taenia hydatigena. Med Vet Sci 19: 48-49.

25. Darzi MM (2002). Pathology of Taeniahydatigenacysticercosis in a naturally infected Corriedale lamb. Vet Parasitol 16(2): 173-174. 